\title{
Angle Class I malocclusion treated with lower incisor extraction
}

Vanessa Leal Tavares Barbosa ${ }^{1}$

In planning orthodontic cases that include extractions as an alternative to solve the problem of negative space discrepancy, the critical decision is to determine which teeth will be extracted. Several aspects must be considered, such as periodontal health, orthodontic mechanics, functional and esthetic alterations, and treatment stability. Despite controversies, extraction of teeth to solve dental crowding is a therapy that has been used for decades. Premolar extractions are the most common, but there are situations in which atypical extractions facilitate mechanics, preserve periodontal health and favor maintenance of the facial profile, which tends to unfavorably change due to facial changes with age. The extraction of a lower incisor, in selected cases, is an effective approach, and literature describes greater post-treatment stability when compared with premolar extractions. This article reports the clinical case of a patient with Angle Class I malocclusion and upper and lower anterior crowding, a balanced face and harmonious facial profile. The presence of gingival and bone recession limited large orthodontic movements. The molars and premolars were well occluded, and the discrepancy was mainly concentrated in the anterior region of the lower dental arch. The extraction of a lower incisor in the most ectopic position and with compromised periodontium, associated with interproximal stripping in the upper and lower arches, was the alternative of choice for this treatment, which restored function, providing improved periodontal health, maintained facial esthetics and allowed finishing with a stable and balanced occlusion. This case was presented to the Brazilian Board of Orthodontics and Dentofacial Orthopedics (BBO), as part of the requirements for obtaining the BBO Diplomate title.

Keywords: Crowding. Lower incisor extraction. Gingival recession.

No planejamento ortodôntico de casos que incluem extrações como alternativa para solucionar o problema de discrepância de espaço negativa, a decisão crítica é determinar quais dentes serão extraídos. Devemos considerar vários aspectos, como a saúde periodontal, mecânica ortodôntica, alterações funcionais e estéticas, e estabilidade do tratamento. Apesar das controvérsias, a extração de dentes para solucionar apinhamentos dentários é uma terapêutica que tem sido utilizada há décadas. As extrações de pré-molares são as mais comuns, mas há ocasiões em que extrações atípicas facilitam a mecânica, preservam a saúde periodontal e favorecem a manutenção do perfil, que tende a se alterar desfavoravelmente devido às modificações faciais decorrentes da idade. A extração de um incisivo inferior, em casos bem selecionados, é uma abordagem eficiente; e a literatura descreve maior estabilidade pós-tratamento, quando comparada com a opção de extração de pré-molares. O presente artigo relata um caso clínico de uma paciente com má oclusão de Classe I de Angle e apinhamento anterior superior e inferior, face equilibrada e perfil harmonioso. A presença de recessões gengivais e ósseas limitava grandes movimentações ortodônticas. Os molares e pré-molares estavam bem relacionados, e a discrepância concentrava-se principalmente na região anterior da arcada dentária inferior. A extração de um incisivo inferior em posição mais ectópica e com periodonto comprometido, associada a desgastes interproximais nas arcadas superior e inferior, foi a alternativa de escolha para o tratamento, que restabeleceu a função, proporcionando melhoria da saúde periodontal, manteve a estética facial, e permitiu a finalização com uma oclusão estável e equilibrada. Esse caso foi apresentado à diretoria do Board Brasileiro de Ortodontia e Ortopedia Facial (BBO), como parte dos requisitos para obtenção do título de Diplomado pelo BBO.

Palavras-chave: Apinhamento. Extração de incisivo inferior. Recessões gengivais.

${ }^{1}$ Specialist in Orthodontics and Dentofacial Orthopedics, State University of Rio de Janeiro (UERJ). Diplomate of the Brazilian Board of Orthodontics and Dentofacial Orthopedics (BBO).

* Clinical case, category 2, accepted by the Brazilian Board of Orthodontics and Dentofacial Orthopedics, BBO.

How to cite this article: Barbosa VLT. Angle Class I malocclusion treated with lower incisor extraction. Dental Press J Orthod. 2013 May-June;18(3):150-8.
» The author reports no commercial, proprietary or financial interest in the products or companies described in this article.

" The patient displayed in this article previously approved the use of her facial and intraoral photographs.

Contact address: Vanessa Leal Tavares Barbosa

Rua José Alexandre Buaiz, $n^{\circ}$ 160, salas 904/906 - Enseada do Suá / Brazil CEP: 29.050-545 - Vitória/ES - E-mail: vanessa@vlortodontia.com.br 


\section{HISTORY AND ETIOLOGY}

Female patient, Caucasian, searched for orthodontic treatment at age 44, in good general health with no significant medical history. The main complaint was related to crowding in the upper arch, and especially in the lower arch, as well as the gingival recessions, which were increasing over the years (Fig 1). There was a history of caries and unsatisfactory restorations in several teeth. No esthetic complaints were reported. In functional occlusion analysis, it was found that the right and left lateral guides were performed by the first upper and lower premolars. The gingival recession of tooth \#14 was, possibly, due to occlusal overload. Despite no functional guides were present, there were no signs or symptoms of temporomandibular disorders. No orthodontic intervention had been performed before.

\section{DIAGNOSIS}

Regarding facial characteristics the following features were present: A mesocephalic pattern, symmetrical face, normal nasolabial angle, with a straight profile. The lower lip was slightly ahead of the Steiner's line and the patient had difficulty to obtain a passive lip seal. In the intraoral evaluation, it was observed a high number of caries, nasal breathing, Angle Class I malocclusion, with severe lower anterior crowding $(7 \mathrm{~mm}$ negative discrepancy in dental arch analysis) and slight crowding in the upper arch. A reduced overbite was present, with less than $1 / 3$ overlap of the lower incisors, and an almost edge to edge anterior occlusion - except in the region of tooth \#11, which had $3 \mathrm{~mm}$ overjet, due to its protrusion and rotation. The upper midline was inclined. In the transverse direction, there was a constriction of the upper
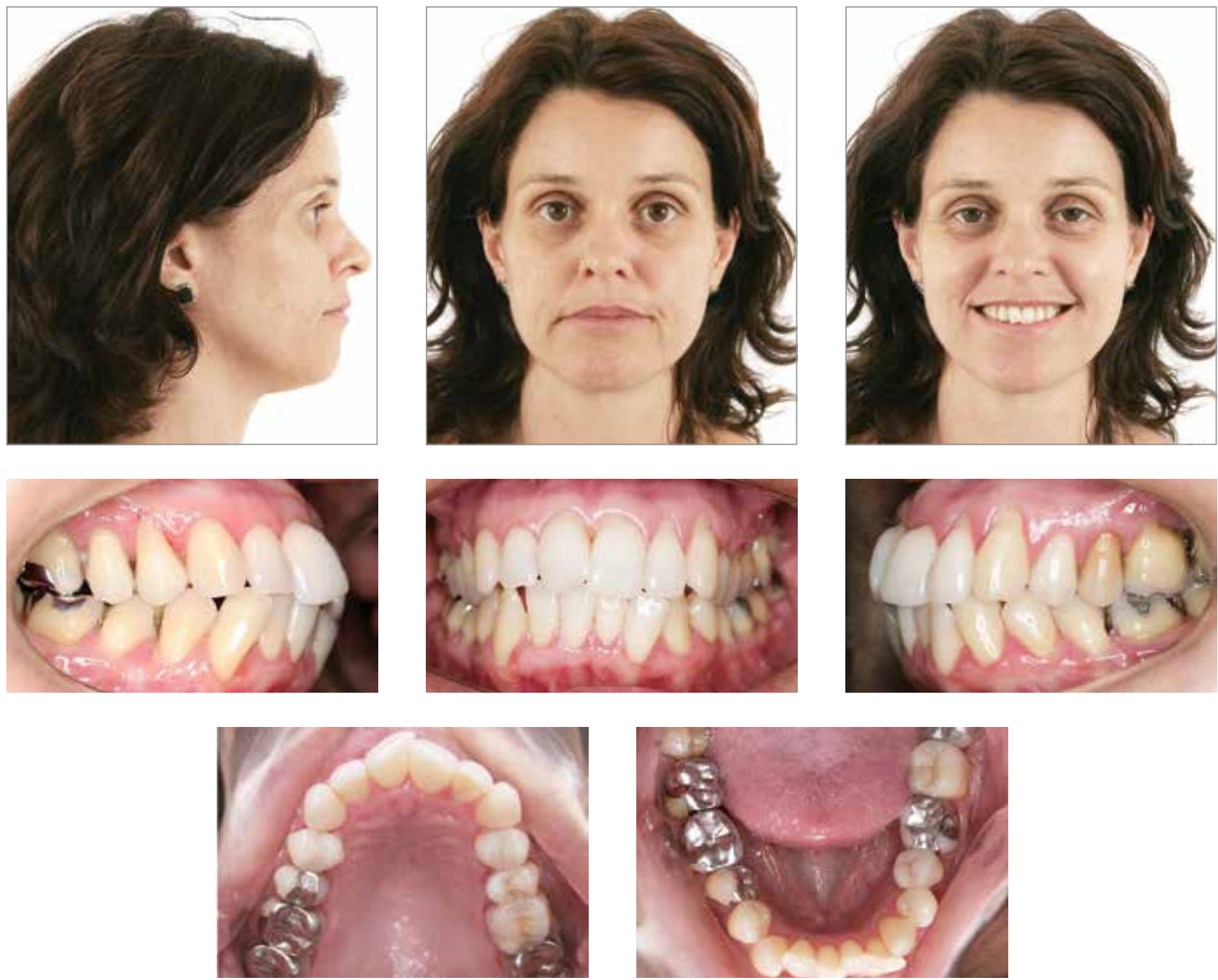

Figure 1 - Initial facial and intraoral photographs. 
arch in the premolars and molars region, with a tendency to crossbite. The lower midline was shifted $1 \mathrm{~mm}$ to the left side, and the upper and lower incisors and lower right canine were projected in relation to their apical bases. Tooth \#43 was labially positioned with the long axis mesially displaced, and presented marked gingival recession (Figs 1 and 2). The panoramic radiograph reported the presence of third molars, with the lower ones mesially tipped. Periapical radiographs revealed a regular alveolar bone loss in the maxilla and mandible, and suggested external root resorption in the apical third of the teeth \#31 and \#41. Interproximal radiographs demonstrated excess of restorative material in several teeth. The cephalometric diagnosis confirmed the labial protrusion of the upper incisors $\left(1-\mathrm{NA}=32^{\circ}\right.$ and $\left.7.5 \mathrm{~mm}\right)$ as well as the lower ones $\left(1-\mathrm{NB}=25^{\circ}\right.$ and $\left.7 \mathrm{~mm}\right)$ (Figs 3, 4 and 5$)$.

\section{TREATMENT OBJECTIVES}

Orthodontic treatment aimed to eliminate the anterior dental discrepancy, correcting the crowding of upper and lower incisors, aligning and leveling the teeth without jeopardizing the facial profile; establishing esthetically favorable and functionally effective overjet and overbite, properly positioning the teeth on their apical bases and contributing to improve periodontal health. The extraction of premolars could result in flattening of the facial profile, aggravated by facial changes due to age; however, the treatment without extractions would increase the lack of lip seal, and contribute to the worsening of gingival recession and a greater tendency to relapse. ${ }^{8}$ Through the diagnostic setup the possibility of a lower incisor extraction was evaluated, because it is one of the most valuable orthodontic records to determine if a lower incisor should be extracted. ${ }^{1,3,11,22,24}$ Prior to orthodontics, the patient would be referred to the periodontist for free gingival graft in the teeth with accentuated gingival recession, preventing its intensification and creating a thicker marginal gingiva. ${ }^{25}$ The shape of the upper arch should be improved by expanding the molar and premolar regions, which tended to cross, favoring a greater filling of the buccal corridor and broadening the smile. The occlusion key of the right and left molars and left canine would be kept, while the Class I relationship in the right canine should be achieved. Inadequate restorations would be replaced at the end of orthodontic treatment, aiming periodontal health and occlusal stability.
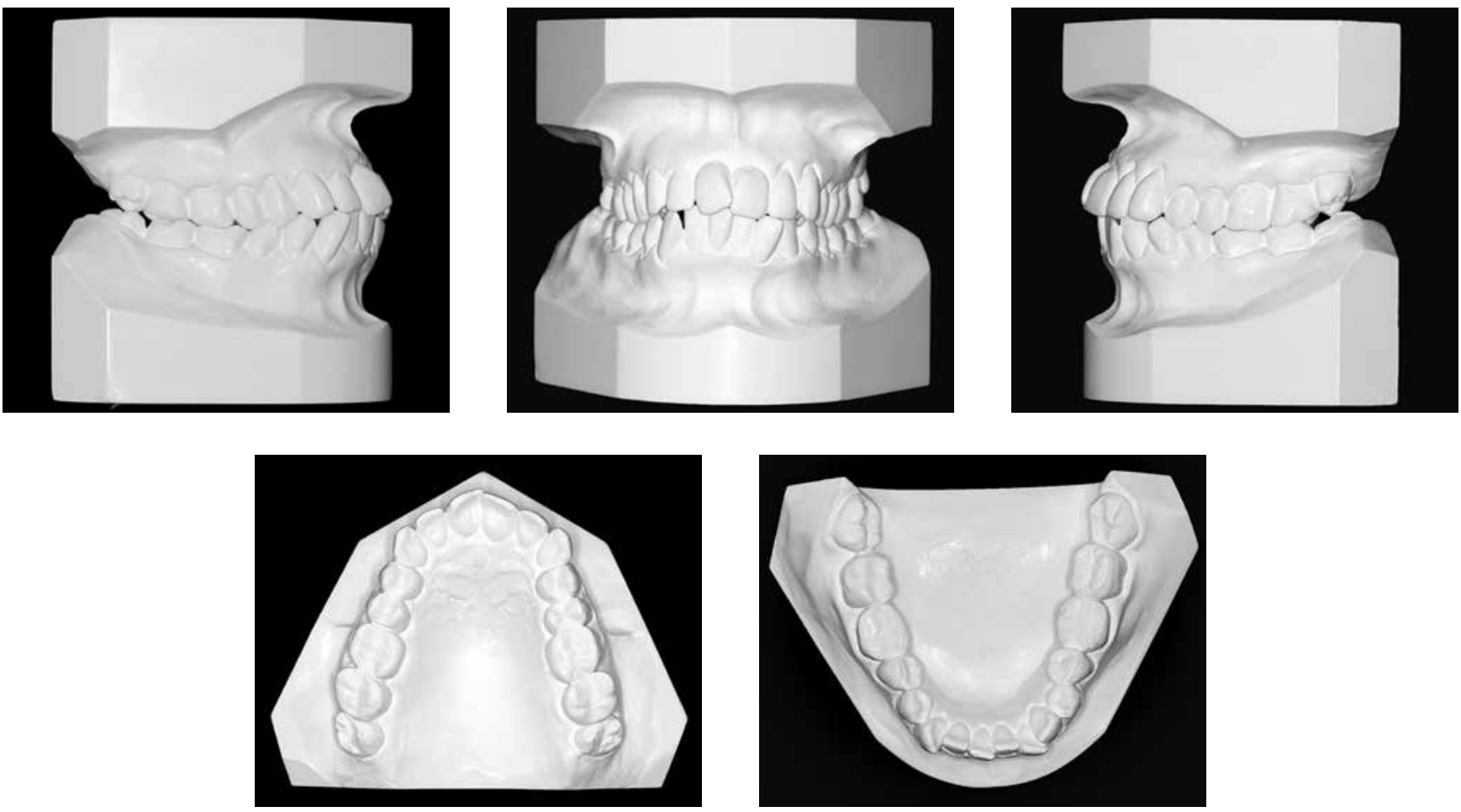

Figure 2 - Initial casts. 

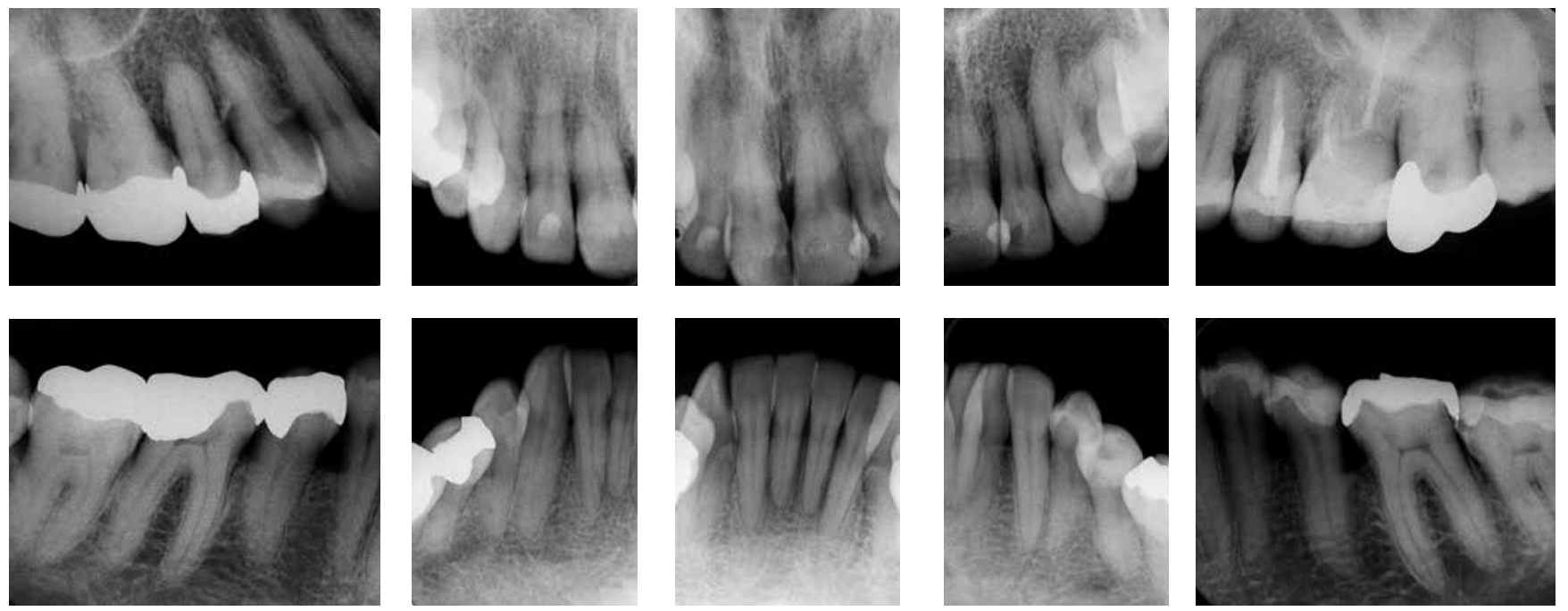

Figure 3 - Initial periapical radiographs.
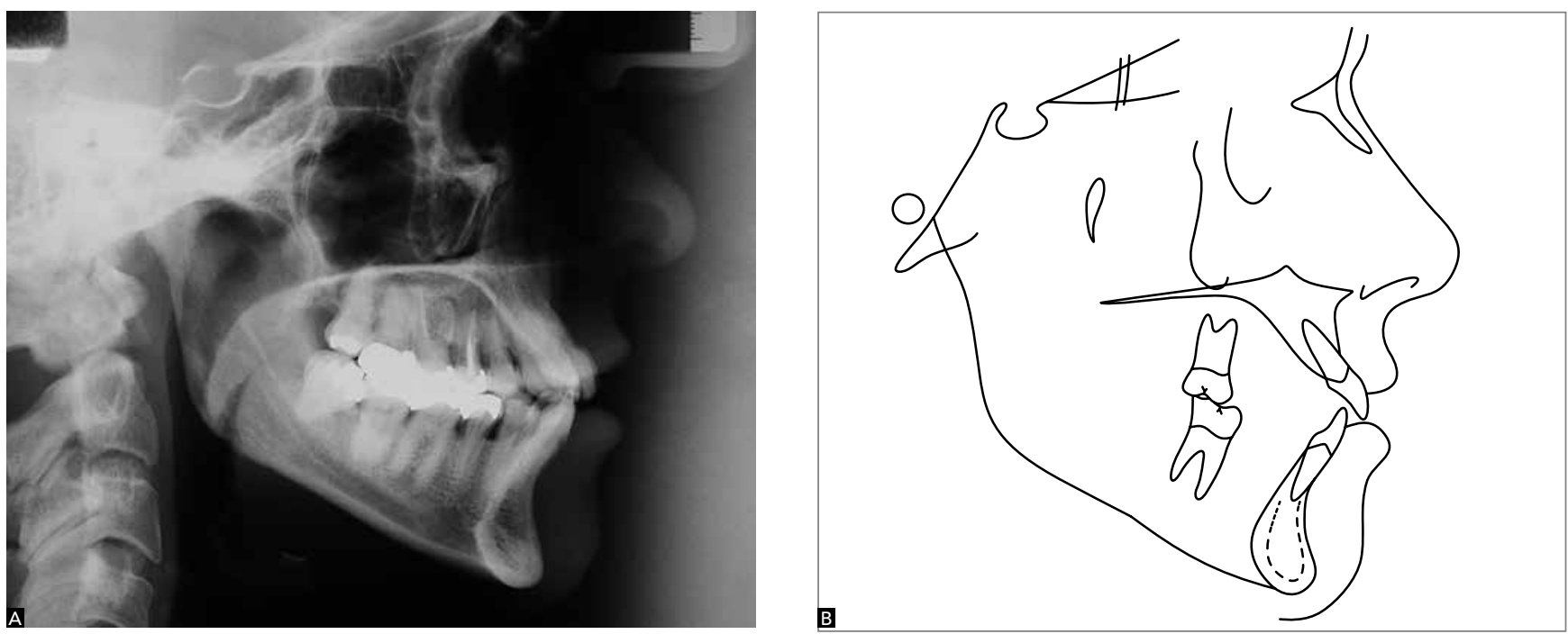

Figure 4 - Initial lateral cephalometric radiograph (A) and cephalometric tracing (B).

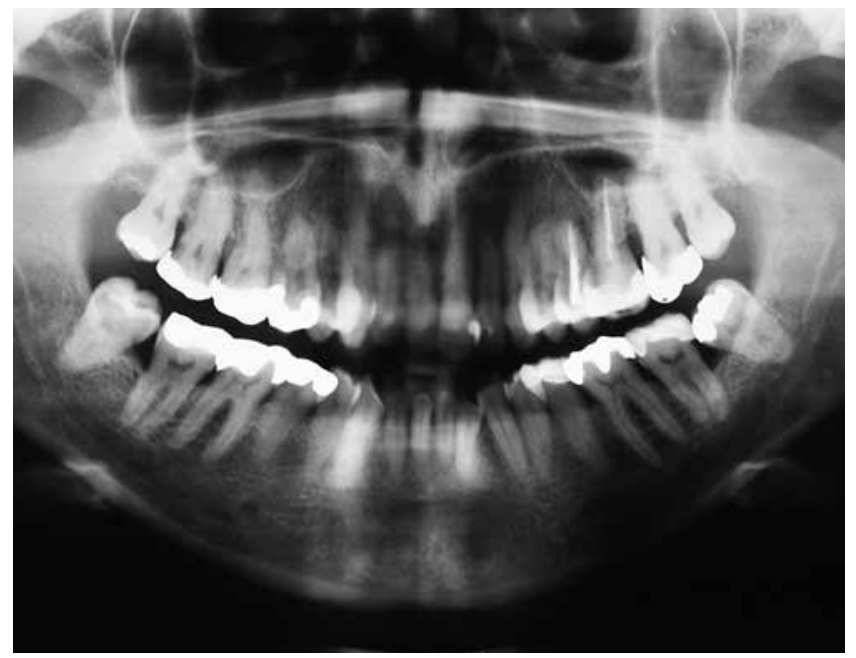

Figure 5 - Initial panoramic radiograph

\section{TREATMENT PLAN}

Performing the diagnostic setup was essential for the decision of the lower incisor extraction, besides helping to visualize treatment outcome and determine the amount of interproximal stripping that would be performed on the upper incisors for proper intercuspation. ${ }^{17,24}$ To indicate the treatment with incisor extraction, some requirements that applied to this case were also considered: Class I molar relationship, mandibular crowding greater than $4.5 \mathrm{~mm}$ (in this case, it was $7 \mathrm{~mm}$ ), slight or nonexistent maxillary crowding (in this case, it was $3 \mathrm{~mm}$ ), balanced soft tissue profile, minimal or moderate overbite and overjet ${ }^{1,7,22,24}$ (Figs 1 and 2). However, before the beginning of orthodontic treat- 
ment, the patient would be referred to the periodontist to control periodontal health conditions and to plan the free graft surgery in teeth with more advanced gingival recession (\#23 and \#43). Only after 60 days these teeth could be moved. For the maxillofacial surgeon, extraction of third molars would be required, because these teeth were in unfavorable positions. After the initial procedures with the multidisciplinary team, orthodontic treatment would start with bonding the brackets on upper and lower dental arches, Straight-Wire system, Roth prescription, slot $0.022 \times 0.028$-in - except in the \#43 tooth, which would not receive a bracket until the space for its alignment in the arch was obtained. Interproximal stripping in the \#45 and \#44 teeth, which presented excess of restorative material, were scheduled in order to optimize the space for the tooth \#43. The finalization would be accomplished through coordinated rectangular arches with ideal torques and shapes, and the use of intermaxillary elastics for final intercuspation. If necessary, it would be requested an occlusal adjustment with the general dentist for occlusion refinement and replacement of initially inadequate restorations.

\section{TREATMENT PROGRESS}

As planned, prior to orthodontics, the patient was referred to the periodontist for the control of periodontal health and conditions and free graft in the region of teeth \#23 and \#43 - to increase the thickness of the marginal gingiva because orthodontic movement could favor the increase of gingival recession and bone fenestrations. ${ }^{9,21,25}$ After 60 days, orthodontic movement in these teeth was permitted. Third molar extraction, which were in unfavorable positions, was also performed at this stage.

Then, brackets were bonded on the upper teeth, Straight-Wire system, Roth prescription, slot $0.022 \times 0.028$-in, on teeth \#17 to \#27. Then, stripping was performed on the upper incisors, with manual abrasive strips, to facilitate alignment, avoid black spaces between these teeth and achieve excellent incisal relationship, by controlling the overbite and reducing overjet - considering that the new occlusal situation would promote articulation of six upper teeth with five lower ones., ${ }^{720,24}$ Alignment and leveling nickel-titanium 0.012-in and 0.014-in archewires were used followed by stainless steel round and 0.014-in, 0.016-in, 0.018-in and 0.020-in archewires. Finishing occurred with $0.019 \times 0.025$-in stainless steel rectangular archwires with ideal shape and torque.
In the mandibular arch a Straight-Wire fixed orthodontic appliance, Roth prescription, slot $0.022 \times 0.028$ in was placed, except in the tooth \#43, which received bracket bonding after opening of space for its alignment and correction of the long axis, which was markedly mesial. Stripping was performed for removal of restorative material excess in teeth \#45 (mesial) and \#44 (distal), and to facilitate the alignment of the tooth \#43. The extraction of the lower left lateral incisor (\#32) was required for being the incisor in the most ectopic position and with the most unfavorable periodontal conditions. ${ }^{6,14}$ The closure of the extraction space was conducted using a passive stainless steel 0.018 -in round archwire and through distal movement of tooth \#31 and mesial movement of the teeth \#41 and \#42 with elastomeric chain and nickel-titanium open spring installed between the teeth \#44 and \#42. Posterior anchorage in the right and left sides was obtained by tying together the molars and premolars with metal ligatures. After obtaining space for tooth \#43, bracket bonding was proceeded, a lower $0.018 \times 0.025$-in stainless steel base archwire with a bypass was made for this tooth and, for its alignment and leveling, a superimposed 0.012-in nickel-titanium sectioned archwire was initially used, followed by a 0.014-in archwire, evolving into continuous arches, for completion of this phase. The finishing was done with $0.018 \times 0.025$-in stainless steel rectangular archwire with ideal form and torques, coordinated with the upper arch. Light triangular 1/4-in intermaxillary elastics were used in the canines and premolars region. Throughout the treatment, the patient was accompanied by the periodontist, with appointments every three months. After verifying the achievement of the goals predefined in the initial planning, the fixed orthodontic appliance was removed, initiating the retention phase. A removable upper wraparound retainer was used as well as a bonded lingual retainer, made with 0.038 -in braided stainless steel wire. The use of the upper retainer plate was recommended for 24 hours a day in the first six months; 18 hours a day, in the following six months; 12 hours a day, for more six months; and then daily use at night.

\section{TREATMENT EVALUATION}

The main treatment goals were achieved. The molar and premolar occlusion, which was very favorable, was maintained and the lower anterior dental crowding, patient's main complaint, was corrected. The correction 

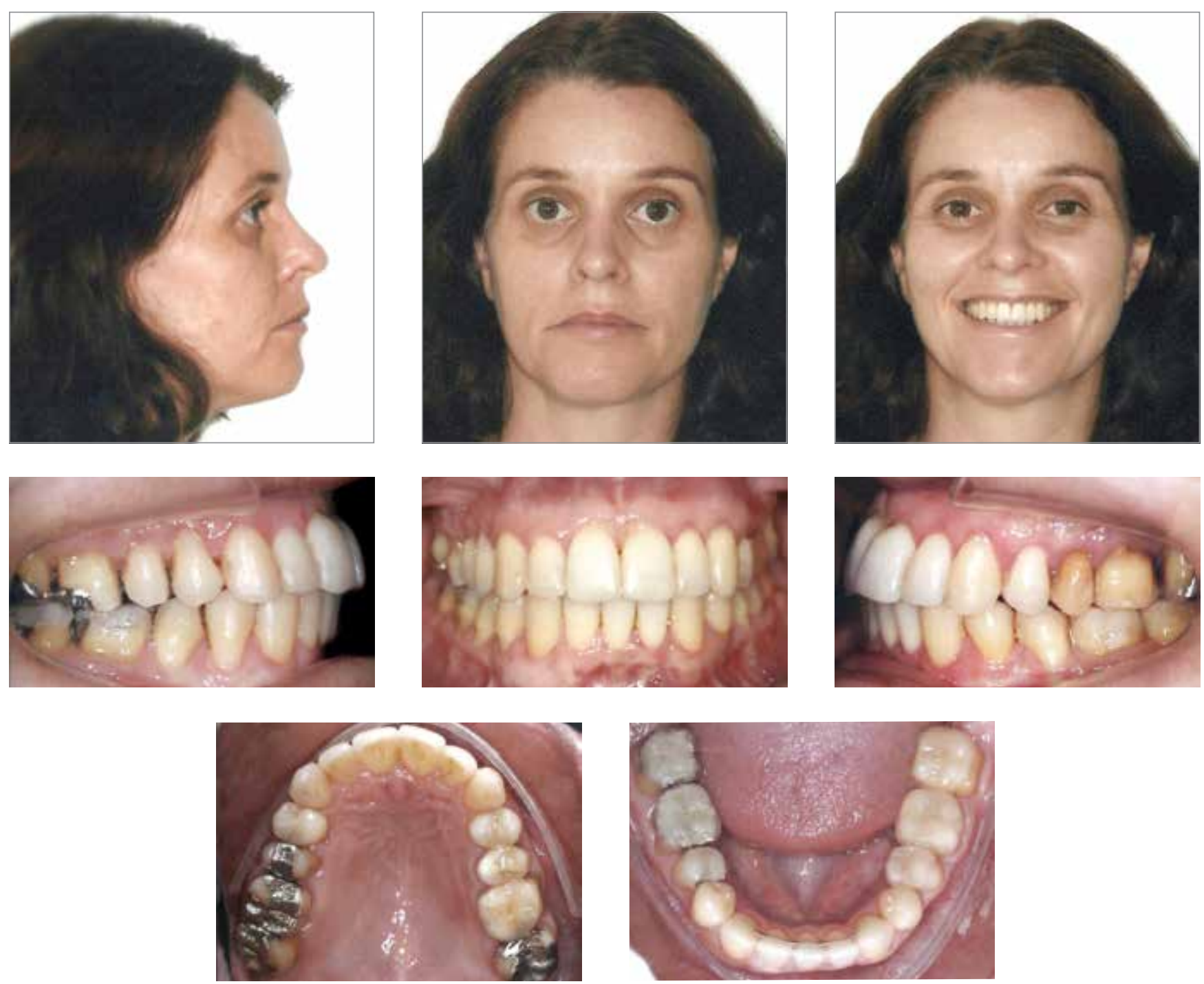

Figure 6 - Final intraoral and facial photographs.

of the axial inclination of the incisors resulted in significant improvement in dental esthetics and reflected in the facial profile, with retraction of the lower lip, from a position $1 \mathrm{~mm}$ forward the $S$ line (Steiner) to $0 \mathrm{~mm}$, favoring passive lip sealing (Table 1). In the frontal photograph, the final smile was more harmonious. The upper midline, which was angled, was corrected and became coincident with the middle of the lower central incisor, without esthetic commitment ${ }^{10,24}$ (Fig 6).

The periodontal health was markedly improved and the increase of overbite and overjet, which had its measures reduced, allowed the establishment of a functionally balanced occlusion (Fig 7).

The left and right molars and left canine keys of occlusion were maintained and the occlusion key on the right canine was achieved, resulting in right and left laterality with disocclusion in the canines and without contacts in balance. The protrusive excursion resulted in adequate posterior disocclusion.

Total superimposition of cephalometric tracings illustrates the profile improvement with the change in the lower lip position, which made it more pleasant (Fig 10A). The partial superimpositions of the maxilla and mandible confirm the significant reduction in labial axial inclination of the upper incisors and discrete uprighting of lower ones, with slight anchorage loss (Fig 10B).

The decision on the extraction of the lateral incisor instead of a central incisor was beneficial because it avoided the presence of an undesirable black triangle between the middle third of the tooth and gingiva, for the distal surface of a central incisor contacts better to mesial surface of a canine. ${ }^{16}$ 

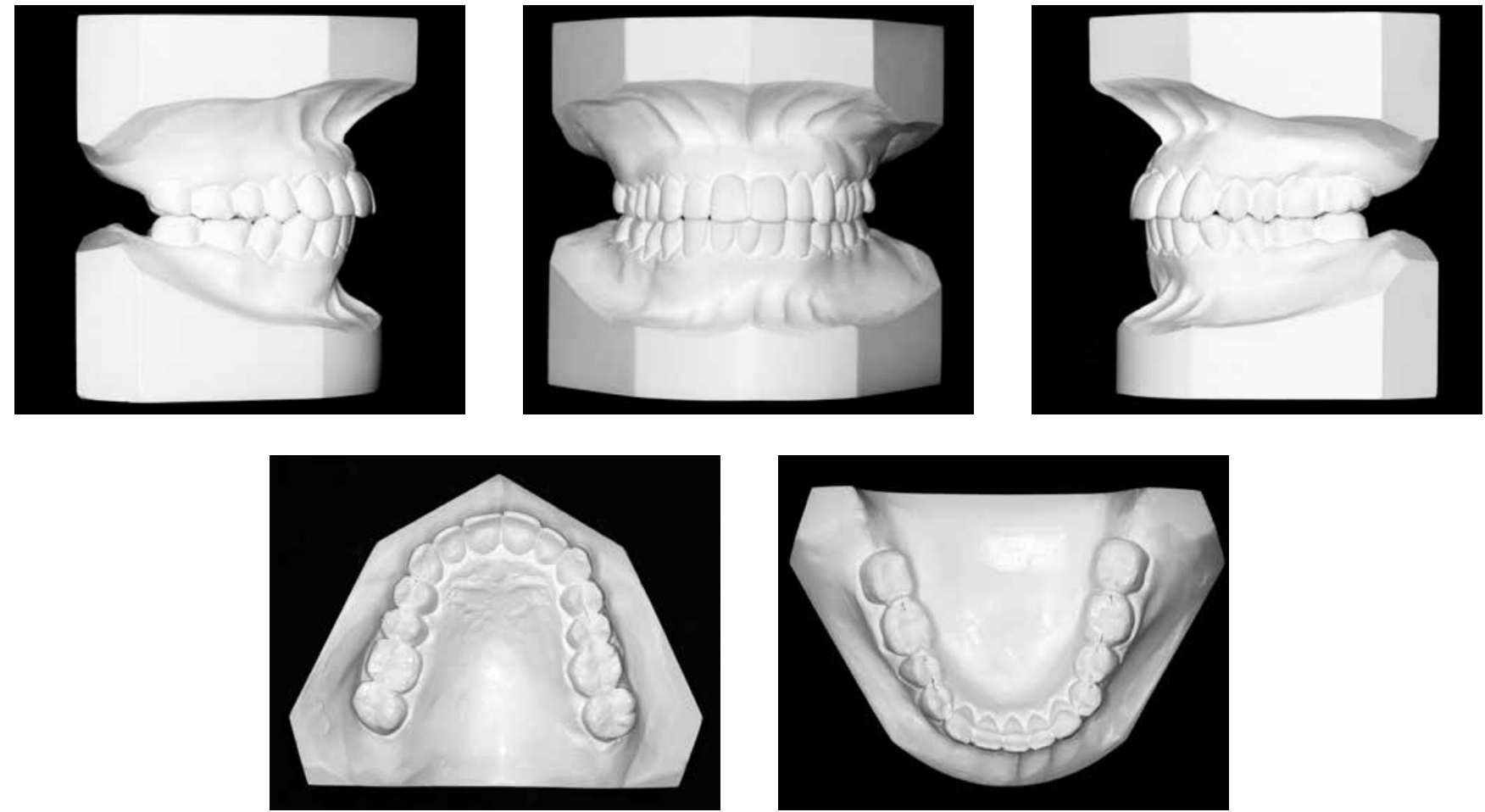

Figure 7 - Final casts.
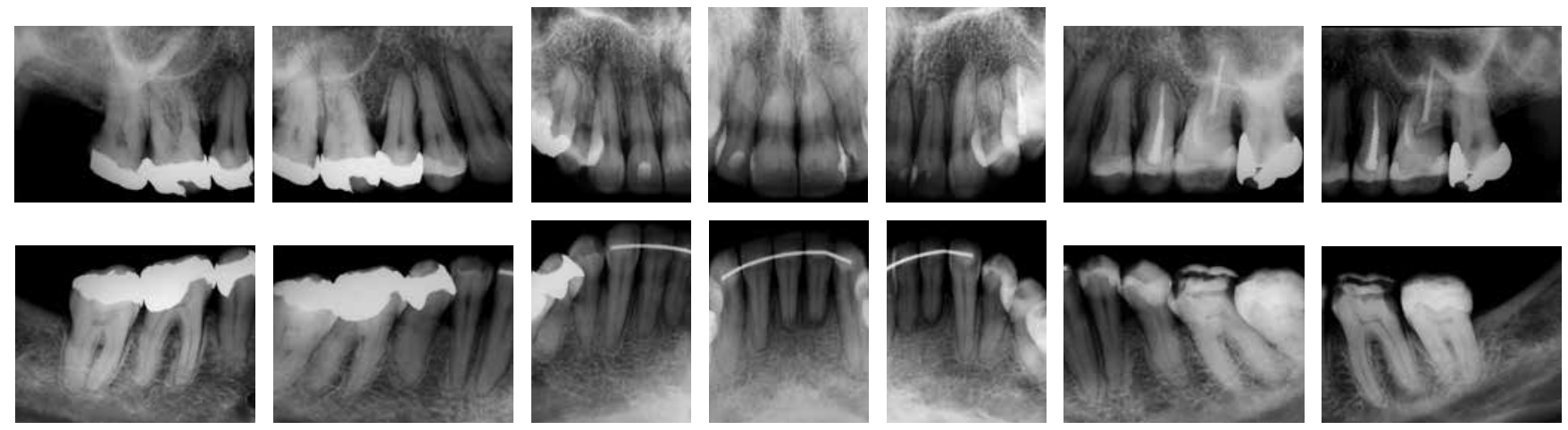

Figure 8 - Final periapical radiographs.
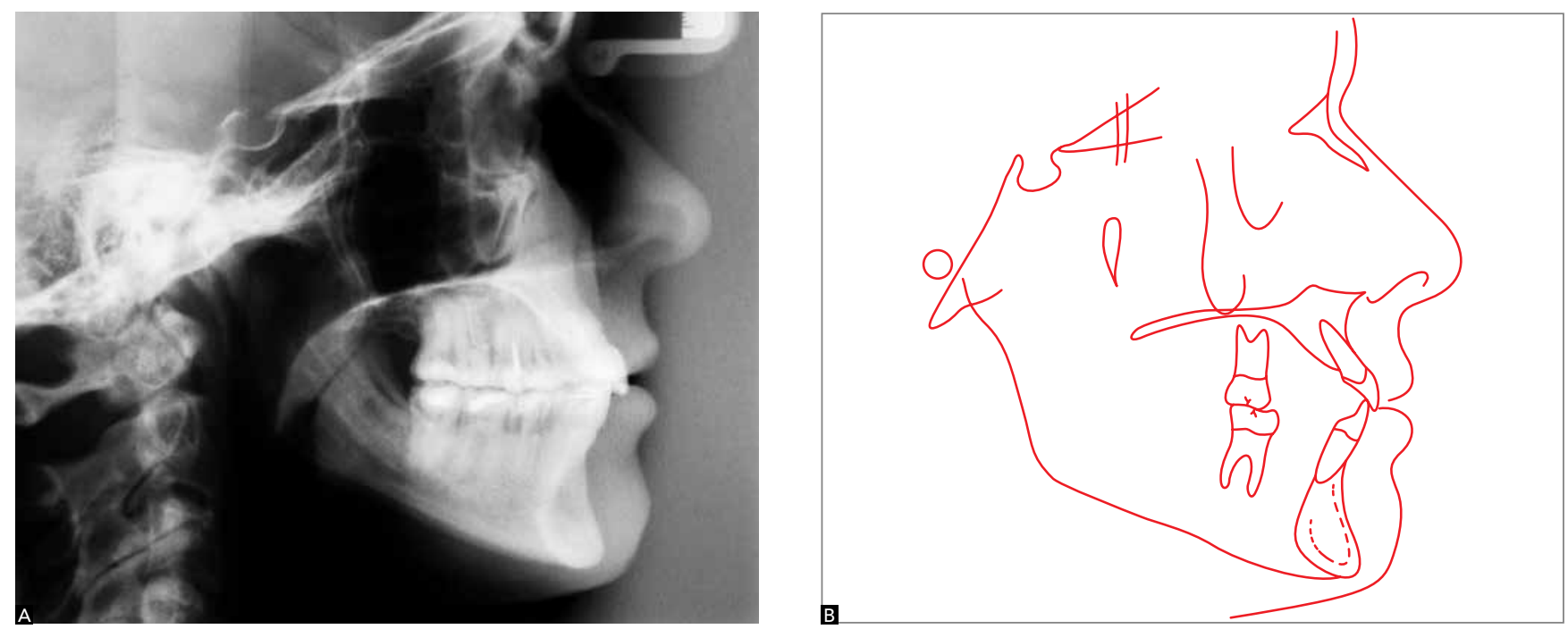

Figure 9 - Final lateral cephalometric radiograph (A) and cephalometric tracing (B). 

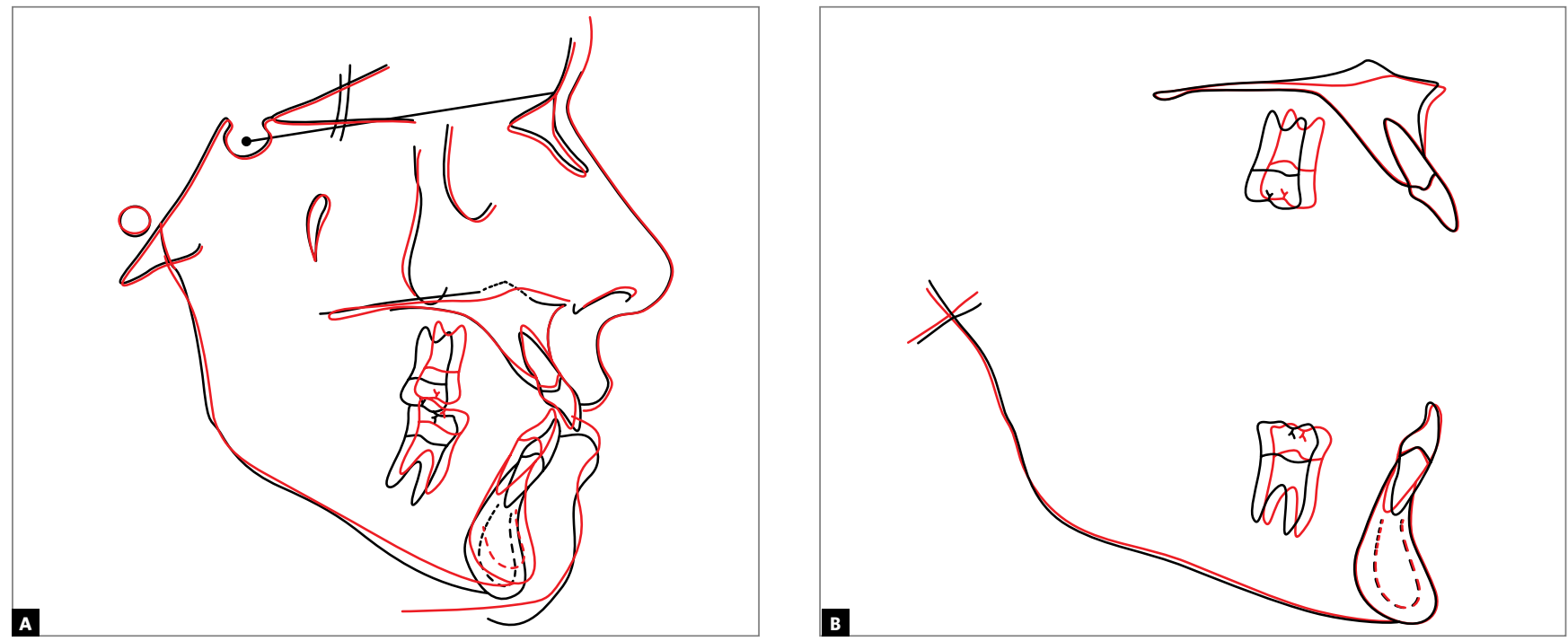

Figure 10 - Total (A) and partial (B) superimpositions of initial (black) and final (red) tracings.

Table 1 - Summary of cephalometric measures.

\begin{tabular}{|c|c|c|c|c|c|c|}
\hline & & & Normal & A & B & A/B diff \\
\hline \multirow{8}{*}{ Skeletal pattern } & SNA & (Steiner) & $82^{\circ}$ & $80^{\circ}$ & $80^{\circ}$ & 0 \\
\hline & SNB & (Steiner) & $80^{\circ}$ & $77^{\circ}$ & $77^{\circ}$ & 0 \\
\hline & ANB & (Steiner) & $2^{\circ}$ & $3^{\circ}$ & $3^{\circ}$ & 0 \\
\hline & Convexity angle & (Downs) & $0^{\circ}$ & $4^{\circ}$ & $3^{\circ}$ & 1 \\
\hline & $Y$ axis & (Downs) & $59^{\circ}$ & $59^{\circ}$ & $58^{\circ}$ & 1 \\
\hline & Facial angle & (Downs) & $87^{\circ}$ & $86^{\circ}$ & $87^{\circ}$ & 1 \\
\hline & SN-GoGn & (Steiner) & $32^{\circ}$ & $35^{\circ}$ & $33^{\circ}$ & 2 \\
\hline & FMA & (Tweed) & $25^{\circ}$ & $28^{\circ}$ & $24^{\circ}$ & 4 \\
\hline \multirow{7}{*}{ Dental pattern } & IMPA & (Tweed) & $90^{\circ}$ & $93^{\circ}$ & $98^{\circ}$ & 5 \\
\hline & 1.NA (degrees) & (Steiner) & $22^{\circ}$ & $32^{\circ}$ & $27^{\circ}$ & 5 \\
\hline & 1-NA (mm) & (Steiner) & $4 \mathrm{~mm}$ & $7,5 \mathrm{~mm}$ & $6 \mathrm{~mm}$ & 1.5 \\
\hline & 1.NB (degrees) & (Steiner) & $25^{\circ}$ & $25^{\circ}$ & $27^{\circ}$ & 2 \\
\hline & I-NB (mm) & (Steiner) & $4 \mathrm{~mm}$ & $7 \mathrm{~mm}$ & $6 \mathrm{~mm}$ & 1 \\
\hline & $\frac{1}{1}$-Interincisal angle & (Downs) & $130^{\circ}$ & $120^{\circ}$ & $120^{\circ}$ & 0 \\
\hline & 1-APo (mm) & (Ricketts) & $1 \mathrm{~mm}$ & $5 \mathrm{~mm}$ & $4 \mathrm{~mm}$ & 1 \\
\hline \multirow{2}{*}{ Profile } & Upper lip - S line & (Steiner) & $0 \mathrm{~mm}$ & $-2 \mathrm{~mm}$ & $-2 \mathrm{~mm}$ & 0 \\
\hline & Lower lip - S line & (Steiner) & $0 \mathrm{~mm}$ & $0 \mathrm{~mm}$ & $-1 \mathrm{~mm}$ & 1 \\
\hline
\end{tabular}

Assessing the intercanine distance, it was found that there was a $1-\mathrm{mm}$ reduction, and it can be said that the maintenance or reduction of this distance during mechanical extraction of incisors is advantageous ${ }^{10}$ compared to premolars, because there is a strong relationship between long-term stability of crowding correction and intercanine distance. It is believed that the treatment with extraction of an incisor and maintenance of that distance or even decreasing it, in anticipation of a further natural decrease, provides bet- ter stability for the final outcome. ${ }^{24}$ However, other authors $^{6,18}$ suggest that the simple maintenance or reduction of intercanine distance during treatment does not guarantee total stability in the long-term, despite contributing to a lower degree of relapse compared to patients treated with premolar extractions. The gingival recession of \#14 tooth was improved, probably due to the removal of occlusal trauma, since prior to the orthodontic treatment, the right side laterality was accomplished by this tooth and the tooth \#44. 
In the evaluation of final periapical radiographs it was observed the absence of the upper and lower third molars, which were removed; and increasing of root apex rounding on the lower incisors (\#41 and \#31), which had already been observed in the initial radiographs (Fig 8). The improvement in axial inclination of \#43 tooth, severely tipped mesially and out of position before treatment, draws attention to its repositioning in the arch and excellent periodontal recovery. The replacement of inadequate restorations was requested at the end of treatment, but had not been completed yet.

\section{FINAL CONCLUSIONS}

The diagnosis and careful planning, with the help of the diagnostic setup, ${ }^{4}$ was essential for the decision of treatment with extraction of a lower incisor. Referring the patient to the periodontist to perform gingival graft before orthodontic treatment enabled orthodontic movement more safely and without injury to teeth already compromised by periodontal recessions. ${ }^{21,25}$

Despite the difficulties or limitations that planning of cases with incisor extraction may result during orthodontic treatment, provided properly conducted and evaluated - considering the particularities of each case - , it can be stated that the lower incisor extraction contributes effectively in the treatment of certain malocclusions, seeking excellence in orthodontic treatment outcomes (maximum function, esthetics and stability). ${ }^{13}$ The patient's satisfaction by having her main complaint resolved reflected also in increased self-esteem and gain of quality of life - benefits provided by orthodontics in the aspect of overall health.

Based on data from the literature and exemplified by the clinical report of this case, it can be concluded that the extraction of a lower incisor is a very effective therapeutic approach in carefully selected situations. ${ }^{15}$
1. Bahreman AA. Lower incisor extraction in orthodontic treatment. Am J Orthod. 1977;72(5):560-7.

2. Bernstein L. Edward H. Angle versus Calvin S. Case: extraction versus nonextraction. Historical revisionism. Part II. Am J Orthod Dentofacial Orthop. 1992;102(6):546-51.

3. Bolognese AM. Set-up: uma técnica de confecção. Rev SOB. 1995:2(8):245-9

4. Bolton WA. Disharmony in tooth size and its relation to the analysis and treatment of malocclusion. Angle Orthod. 1958:28(3):113-30.

5. Brandt S, Safirstein GR. Different extractions for different malocclusions. Am J Orthod. 1975;68(1):15-41.

6. Canut JA. Mandibular incisor extraction: indications long-term evaluation Eur J Orthod. 1996;18(5):485-9

7. Faerovig E, Zachrisson BU. Effects of mandibular incisor extraction on anterior occlusion in adults with Class III malocclusion and reduced overbite. Am J Orthod Dentofacial Orthop. 1999:115(2):113-24.

8. Janson GRP, Canto GDL, Henriques JFC, Freitas MR, Mazziero ET, Toruño JA. A importância da individualização no planejamento ortodôntico. Rev Dental Press Ortod Ortop Facial. 1998;8(2):31-45.

9. Holmes HD, Tennant M, Goonewardene MS. Augmentation of faciolingual gingival dimensions with free connective tissue grafts before labial orthodontic tooth movement: an experimental study with a canine model. Am J Orthod Dentofacial Orthop. 2005:127(5):562-72

10. Klein DJ. The mandibular central incisor, an extraction option. Am J Orthod Dentofacial Orthop. 1997:111(3):253-9

11. Kokich VG, Shapiro PA. Lower incisor extraction in orthodontic treatment Four clinical reports. Angle Orthod. 1984;54(2):139-53.

12. Kokich VO. Treatment of a Class I malocclusion with a carious mandibular incisor and no Bolton discrepancy. Am J Orthod Dentofacial Orthop. 2000;118(1):107-13.
13. Lima CMF, Lacet E, Marques CR. Extração de incisivo inferior: uma opção terapêutica. Rev Dental Press Ortod Ortop Facial. 2005;10(4):47-59.

14. Little RM, Riedel RA, Artun J. An evaluation of changes in mandibular anterior alignment from 10 to 20 years postretention. Am J Orthod Dentofacial Orthop. 1988;93(5):423-8

15. Matsumoto MAN, Romano FL, Ferreira JTL, Tanaka S, Morizono EN Extração de incisivo inferior: uma opção de tratamento ortodôntico. Rev Dental Press Ortod Ortop Facial. 2010;15(6):143-61

16. Neff $\mathrm{CW}$. The size relationship between the maxillary and mandibular anterior segments of the dental arch. Angle Orthod. 1957:27(3):138-47.

17. Owen $\mathrm{AH}$. Single lower incisor extractions. J Clin Orthod. 1993:27(3):153-60

18. Riedel RA, Little RM, Bui TD. Mandibular incisor extraction: postretention evaluation of stability and relapse. Angle Orthod. 1992;62(2):103-16

19. Rosenstein SW. A lower incisor extraction. Aust Orthod J. 1976:4(3):107-9

20. Sheridan JJ, Hastings J. Air-rotor stripping and lower incisor extraction treatment. J Clin Orthod. 1992;22(4):187-204

21. Tanaka O, Young Lon B, Taffarel IP, Siu Lon LF, OLiveira-Junior SR. A recessão e o enxerto gengival no tratamento ortodôntico. Orthod Sci Pract. 2008;1(1):37-47

22. Telles CS, Urrea BEE, Barbosa CAT, Jorge EVF, Prietsch JR, Menezes LM, et al. Diferentes extrações em Ortodontia (sinopse). Rev SOB. 1995:2(2):194-9.

23. Tuverson DL. Anterior interocclusal relations. Part II. Am J Orthod. 1980;78(4):371-93.

24. Valinoti JR. Mandibular incisor extraction therapy. Am J Orthod Dentofacial Orthop. 1994:105(2):107-16

25. Wennström J, Pini Prato GP. Terapia mucogengival. In: Lindhe J. Tratado de Periodontia clínica e Implantologia oral. 3a ed. Rio de Janeiro: GuanabaraKoogan; 1999. p. 393- 427. 